\title{
Relationships between soil-litter interface enzyme activities and decomposition in Pinus massoniana plantations in China
}

\author{
Xiaogai Ge ${ }^{1,2} \cdot$ Wenfa Xiao $^{2} \cdot$ Lixiong Zeng ${ }^{2}$ - Zhilin Huang ${ }^{2}$ Benzhi Zhou ${ }^{1}$. \\ Marcus Schaub ${ }^{3} \cdot$ Mai-He $\mathrm{Li}^{3,4}$
}

Received: 28 January 2016 / Accepted: 31 October 2016/Published online: 29 November 2016

(C) Springer-Verlag Berlin Heidelberg 2016

\begin{abstract}
Purpose Enzyme activities in decomposing litter are directly related to the rate of litter mass loss and have been widely accepted as indicators of changes in belowground processes. Studies of variation in enzyme activities of soil-litter interface and its effects on decomposition are lacking. Evaluating enzyme activities in this layer is important to better understand energy flow and nutrient cycling in forest ecosystems.

Materials and methods Litter decomposition and the seasonal dynamics of soil-litter enzyme activities were investigated in situ in 20- (younger) and 46-year-old (older) Pinus massoniana stands for 540 days from August 2010 to March 2012 by litterbag method. We measured potential activities of invertase, cellulase, urease, polyphenol oxidase, and peroxidase in litter and the upper mineral soils, and evaluated their relationships with the main environment factors.

Results and discussion Remaining litter mass was $57.6 \%$ of the initial weights in the younger stands and $61.3 \%$ in the
\end{abstract}

Responsible editor: Chengrong Chen

Lixiong Zeng

zlxcaf@163.com

Mai-He Li

maihe.li@wsl.ch

1 Research Institute of Subtropical Forestry, Chinese Academy of Forestry, Hangzhou, Zhejiang 311400, China

2 State Forestry Administration Key Laboratory of Forest Ecology and Environment, Research Institute of Forest Ecology, Environment and Protection, Chinese Academy of Forestry, Beijing 100091, China

3 Swiss Federal Research Institute WSL, Zuercherstrasse 111, 8903 Birmensdorf, Switzerland

4 Institute of Applied Ecology, Chinese Academy of Sciences, Shenyang 110164, China older stands after 540-day decomposition. Levels of enzyme activity were higher in the litter layer than in the soil layer. Soil temperature, litter moisture, and litter nitrogen $(\mathrm{N})$ concentration were the most important factors affecting the enzyme activities. The enzyme activity showed significantly seasonal dynamics in association with the seasonal variations in temperature, water, and decomposition stages. Remaining litter dry mass was found to be significantly linearly correlated with enzyme activities (except for litter peroxidase), which indicates an important role of enzyme activity in the litter decomposition process.

Conclusions Our results indicated the important effects of biotic (litter N) and abiotic factors (soil temperature and litter moisture) on soil-litter interface enzyme activities. Overall significant linear relationship between remaining dry mass and enzyme activities highlighted the important role of enzyme activity in affecting litter decomposition processes, which will further influence nutrient cycling in forest ecosystems. Our results contributed to the better understanding of the mechanistic link between upper soil-litter extracellular enzyme production and litter decomposition in forest ecosystems.

Keywords Hydrolase activity $\cdot$ Litter decomposition . Oxidoreductase activity $\cdot$ Pinus massoniana $\cdot$ Soil-litter layer enzyme

\section{Introduction}

Plant litter on forest floors is an important nutrient source (Sundarapandian and Swamy 1999) as it provides soil organic matter to sustain nutrient cycling by soil microorganisms (Kourtev et al. 2002). Plant litter and its decomposition might be important in understanding soil nutrient cycling and soil- 
litter interactions (Sariyildiz 2008), and the litter decomposition rate is a critical determinant of forest productivity (Prescott 2005). Generally, an accumulation of large nutrient stocks in soil surface horizons is a result of slow litter decomposition rate (Melillo et al. 1982; Wang et al. 2013), and at the microbial level, the activity of extracellular enzymes primarily regulates the plant litter decomposition rate (Sinsabaugh et al. 1991; Smart and Jackson 2009). Moorhead and Sinsabaugh (2000) found that litter decomposition was influenced by the activities of extracellular enzymes. Waring (2013) showed that extracellular enzymes were important factors influencing leaf litter decay and explained $35 \%$ of the variance in leaf decay rates. Therefore, microbial enzyme dynamics might affect overall rates of litter decomposition. Studies on dynamic changes in enzyme activity during litter decomposition could provide important information for decay dynamics and functional microbial succession in forest ecosystems (Fioretto et al. 2000; Qasemian et al. 2012). However, spatial and temporal variations in soil-litter interface enzyme activities, and the effects of litter on the activity of soil-litter enzymes during litter decomposition are still not well understood $(\mathrm{Hu}$ et al. 2006)

Microbial enzymes in the soil-litter interface are involved in the decomposition of litter and soil organic matter. Enzyme activities in decomposing litter were directly correlated with litter decomposition rate (Kourtev et al. 2002) which has been used in developing litter decomposition models to better understand litter decomposition processes (Andersson et al. 2004). The effects of enzyme (e.g., hydrolase) activities on the decay of major litter components have been found to couple with major nutrient cycles, such as nitrogen $(\mathrm{N})$, phosphorus (P), and sulfur (S) cycle (Fioretto et al. 2000). It has been shown that oxidative enzymes including phenol oxidase and peroxidase mediate lignin degradation, humification, carbon (C) mineralization, and dissolved organic $\mathrm{C}$ export (Zhou and Zhang 2014). Sinsabaugh and Moorhead (1994) suggested that enzyme activity can be used as indicators to estimate the decomposition rate and to assess the relative $\mathrm{N}$ and $\mathrm{P}$ availability. Using enzyme activities to study plant litter decomposition is a potential approach for a conceptual model of plant litter degradation from an enzymatic perspective (Sinsabaugh et al. 1991).

Previous studies have examined the relationships between litter decomposition rate and enzyme activities in different forest ecosystems with various tree species (Allison and Vitousek 2004), forest age (Ma et al. 2014), and soil environments (Baldrian et al. 2013), but they did not get consistent results. Waring (2013) observed that decomposition rates were positively correlated with $\beta-1,4-$ glucosidase, cellobiohydrolase, and acid phosphatase. Allison and Vitousek (2004) emphasized that litter decomposition rate was positively correlated with soil phenol oxidase activity, but it was not related to litter enzyme activity. Joshi et al.
(1993) noted that enzyme activities were interrelated with litter chemical properties and environmental factors. Kshattriya et al. (1992) suggested that the age of the forest where the litter was examined did not have a consistent effect on litter layer enzyme activities, and the activities of cellulase and amylase showed a marked seasonal variation. Kourtev et al. (2002) showed that enzyme activities in decomposing litter could be directly affected by litter chemistry and soil characteristics including soil moisture, temperature, and available nutrients (Kotroczó et al. 2014).

To improve the accuracy of decomposition models, it is necessary to explain how microbial characteristics and decomposition rates respond to variations in climate and edaphic factors. We, therefore, assessed the relationships of soil and litter layer enzyme activities with decomposition rate in younger and older Pinus massoniana plantations, and examined the effects of microclimate on litter decomposition rate and enzyme activities. We aimed to test two specific hypotheses linking enzyme allocation strategies to litter decomposition: (I) Litter decomposition rates are positively correlated with soil-litter enzyme activities and (II) enzyme activities in litter and soil are determined by the same factors such as soil water content, temperature, and litter chemistry. The present study will contribute to better understand the potential relationships between litter decomposition rate and soil-litter enzyme activities in relation to the forest carbon budget and dynamics in different-aged P. massoniana forests.

\section{Materials and methods}

\subsection{Study site}

The study was carried out in the Forest Ecological Research Station in Zigui County $\left(110^{\circ} 00^{\prime} 14^{\prime \prime}-111^{\circ} 18^{\prime} 41^{\prime \prime}\right.$ E, $30^{\circ} 38^{\prime}$ $14^{\prime \prime}-31^{\circ} 11^{\prime} 31^{\prime \prime} \mathrm{N}$, elevation 40-2057 m.a.s.1.), Hubei Province, China. Meteorological parameters were measured at the nearby weather station $(<3 \mathrm{~km}$ away from the study sites). The study area has a subtropical monsoon climate, and the mean annual temperature is $17-19{ }^{\circ} \mathrm{C}$ with January being the coldest month (minimum temperature $-2.5^{\circ} \mathrm{C}$ ) and July/August the warmest months (maximum temperature $44{ }^{\circ} \mathrm{C}$ ) (Fig. 1). Mean annual precipitation in the area is 1000-1250 mm, with precipitation mainly occurring from April to September. The soil at the study site is a haplic luvisol (Gong 2003), and the soil depth was 70-100 cm at all sites.

Three spatially separated younger $P$. massoniana stands (20 years old, $n=3$ ) and three older $P$. massoniana stands (46 years old, $n=3$ ) at similar elevations $( \pm 50 \mathrm{~m})$ were selected for the present study. Each stand covered an area of $>1$ ha. In the center of each stand, a $20 \times 30$-m plot was established in June 2010. Litter decomposition rates and soil enzyme activities were determined in each plot. The plantations were pure 
Fig. 1 Monthly air temperature and precipitation during $2010.01-$ 2011.12 in ZiguiCounty

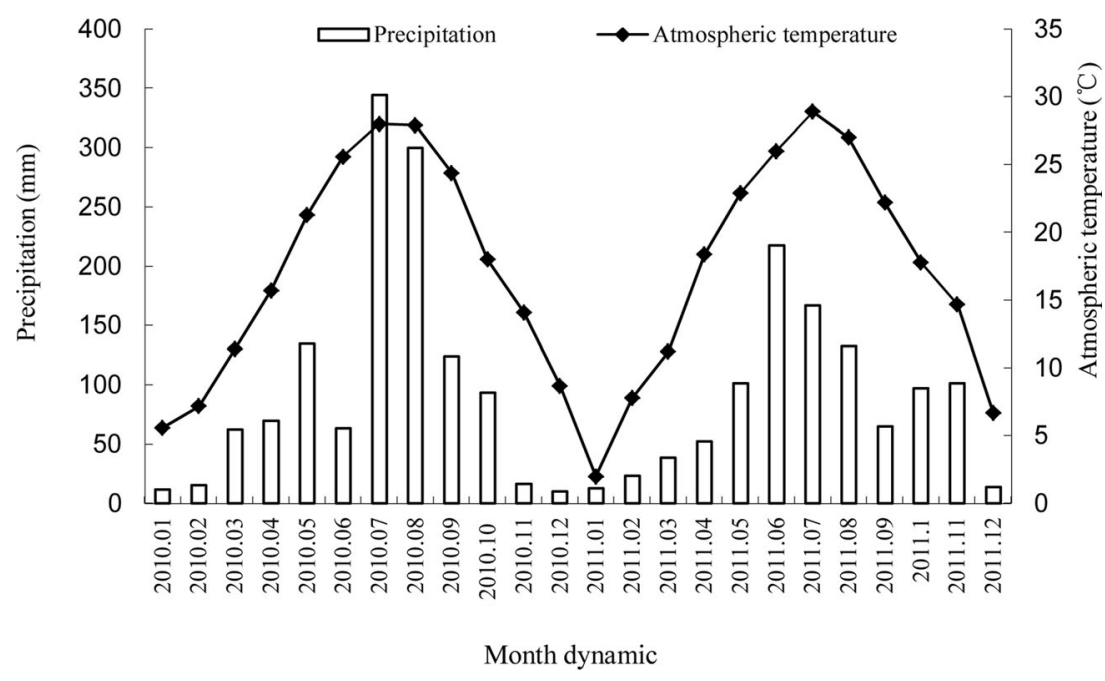

P. massoniana stands with the dominant understory shrubs of Camellia oleifera, Loropetalum chinense, and Cotinus coggygria, and the dominant herbaceous species of Echinochloa crusgalli, and Veronicastrum villosulum (Xiao et al. 2014). Plot characteristics were summarized in Table 1.

\subsection{Litter decomposition experiment and soil sampling}

The nylon net litterbag technique was applied to determine the rate of leaf litter decomposition (Xuluc-Tolosa et al. 2003; Song et al. 2012). Freshly senesced leaf litter in each stand was collected using litter boxes from March to May 2010 and then air dried in laboratory for 2 months. Twenty grams of airdried leaf litter was placed into each $20 \times 20$-cm nylon bag with 1-mm mesh. A total of 216 litterbags ( 6 collection times, 6 replications collected each time, 3 stands for each forest type, and 2 forest types) were employed in situ in early August 2010. The litter bags were randomly placed on soil surface after removing the surface litter. Sub-samples of airdried leaf litter were oven-dried at $70^{\circ} \mathrm{C}$ to constant weight for calculating the conversion coefficient between air-dried and oven-dried leaf litter.

Litterbags were fastened to soil surfaces using steel stakes. Eighteen litter bags from each stand type were retrieved after 90 days (November 2010), 180 days (March 2011), 270 days (June 2011), 360 days (September 2011), 450 days (November 2011), and 540 days (March 2012) in situ decomposition. After collection, each litterbag was opened and brushed to remove the external soil and litter. Then, one half of the litter was stored at $4{ }^{\circ} \mathrm{C}$ for litter layer enzyme activity analysis within 1 week and the other half was oven-dried at $70{ }^{\circ} \mathrm{C}$ for $48 \mathrm{~h}$. The remaining litter was then weighed and the percentage of the remaining mass was calculated.

To investigate initial soil properties, three soil cores $(0$ $20 \mathrm{~cm}$ deep) by diagonal method were collected from each plot in August 2010, using a hand auger (5-cm inner diameter), and pooled to get one soil sample for each plot ( $n=3$ for each stand). To assess the relationships between soil enzyme activities and litter decomposition, soil cores (0-5 cm deep) were collected directly below each of the six decomposition bags retrieved at 90 days (November 2010), 180 days

Table 1 Summary of stand characteristics measured in summer 2010

\begin{tabular}{|c|c|c|c|c|c|c|c|c|c|}
\hline Stands & $\begin{array}{l}\text { Elevation } \\
\text { (a.s.l.) }\end{array}$ & $\begin{array}{l}\mathrm{DBH} \\
(\mathrm{cm})\end{array}$ & $\begin{array}{l}\text { Height } \\
\text { (m) }\end{array}$ & $\begin{array}{l}\text { Slope } \\
\left({ }^{\circ}\right)\end{array}$ & $\begin{array}{l}\text { Stand density } \\
\left(\text { tree } \mathrm{ha}^{-1} \text { ) }\right.\end{array}$ & $\begin{array}{l}\text { Standing crop } \\
\left(\mathrm{t} \mathrm{ha}^{-1}\right)\end{array}$ & $\begin{array}{l}\text { Annual } \\
\text { litterfall( }\left(\mathrm{tha}^{-1}\right)\end{array}$ & $\begin{array}{l}\text { Litter layer } \\
\text { depth/(cm) }\end{array}$ & $\begin{array}{l}\text { Fine root biomass } \\
\left(\mathrm{t} \mathrm{ha}^{-1}\right)\end{array}$ \\
\hline $\begin{array}{c}\text { Younger } \\
1\end{array}$ & 972 & 13.4 & $12.3-18.4$ & 20 & 813 & $42.44 \pm 8.05$ & $1.79 \pm 0.67$ & $1.18 \pm 0.03$ & $4.72 \pm 0.21$ \\
\hline $\begin{array}{c}\text { Younger } \\
2\end{array}$ & 964 & 16.1 & $15.6-19.0$ & 21 & 800 & $54.88 \pm 17.24$ & $2.35 \pm 0.79$ & $1.24 \pm 0.03$ & $3.91 \pm 0.19$ \\
\hline $\begin{array}{l}\text { Younger } \\
3\end{array}$ & 956 & 18.8 & $14.8-19.6$ & 19 & 787 & $58.39 \pm 9.12$ & $2.95 \pm 0.51$ & $0.97 \pm 0.01$ & $5.53 \pm 0.13$ \\
\hline Older 1 & 970 & 35.5 & $16.0-23.9$ & 16 & 586 & $57.44 \pm 7.34$ & $2.65 \pm 0.59$ & $0.98 \pm 0.04$ & $2.94 \pm 0.21$ \\
\hline Older 2 & 987 & 33.1 & $18.4-24.8$ & 17 & 575 & $70.95 \pm 9.64$ & $3.28 \pm 0.73$ & $1.03 \pm 0.02$ & $3.35 \pm 0.17$ \\
\hline Older 3 & 1004 & 30.7 & $19.1-25.7$ & 15 & 564 & $80.46 \pm 8.02$ & $4.05 \pm 0.55$ & $1.24 \pm 0.05$ & $2.53 \pm 0.15$ \\
\hline
\end{tabular}

$D B H$ diameter at breast height 
(March 2011), 270 days (June 2011), and 360 days (September 2011). These four sampling dates across 360 decomposition days roughly represented a 1-year cycle. Visible roots and organic residues were removed from the samples. Each sample was divided into two sub-samples: one was freshly sieved (2-mm mesh) and stored at $4{ }^{\circ} \mathrm{C}$ for soil enzyme activity analysis within 1 week, and the other one was air dried and finely ground to pass through a $0.25-\mathrm{mm}$ sieve for other analyses (e.g., soil organic matter, soil total N, soil available P). Unfortunately, the soil samples taken at 180 days got lost during transport, so that the materials were not enough to analyze all enzyme activities in the laboratory.

\subsection{Analysis of upper soil-litter interface enzymes activities and mineral elements}

Methodology for this work was based on "Observation Methodology for Long-term Forest Ecosystem Research" (Forestry Standards of People's Republic of China, LY/T 1952-2011). All enzyme activities were measured using the assay techniques modified from Wang et al. (2008) and Guan (1986). To ensure that assays are being performed on consistent soil or litter fractions, soil samples were passed through a 2-mm screen, and $1 \mathrm{~g}$ fresh decomposing litter sample was chopped into smaller piece and passed through a $2-\mathrm{mm}$ screen, then followed by oscillation with $0.05 \mathrm{M}$ of acetic acid buffer $(\mathrm{pH} 5)$ and centrifuged, filtrated before homogenization (German et al. 2011; Talbot et al. 2015).

The invertase activity was measured by incubating the soil or litter homogenization with $15 \mathrm{~mL}$ of $8 \%$ sucrose and $5 \mathrm{~mL}$ of phosphate buffer (pH 5.5) at $37^{\circ} \mathrm{C}$ for $24 \mathrm{~h}$, and measuring the reducing sugars (glucose) using colorimetry at $508 \mathrm{~nm}$ with 3,5-dinitrosalicylic acid. The results were expressed as milligrams glucose per gram per $24 \mathrm{~h}$. The cellulase activity was measured by incubating the soil or litter homogenization with $2 \mathrm{~mL}$ of $1 \%$ carboxymethyl cellulase, $1.5 \mathrm{~mL}$ of methylbenzene, and $5 \mathrm{~mL}$ of phosphate buffer ( $\mathrm{pH} 5.5$ ) at $37^{\circ} \mathrm{C}$ for $72 \mathrm{~h}$ and measuring the reducing sugars (glucose) using colorimetry at $540 \mathrm{~nm}$ with 3,5-dinitrosalicylic acid. The results were expressed as milligrams glucose per gram per $72 \mathrm{~h}$. The urease activity assay was based on the $\mathrm{NH}_{4}{ }^{+}$ released when the soil or litter homogenization was incubated with $10 \mathrm{~mL}$ of $10 \%$ urea solution and $20 \mathrm{~mL}$ of citric acid buffer (pH 6.7) at $37{ }^{\circ} \mathrm{C}$ for $24 \mathrm{~h}$. The released $\mathrm{NH}_{4}{ }^{+}$was determined using the indophenol blue method, and the results were expressed as $\mathrm{mg} \mathrm{NH}_{4}{ }^{+}-\mathrm{N} \mathrm{g}^{-1} 24 \mathrm{~h}^{-1}$.

Polyphenol oxidase activity was measured by incubating the soil or litter homogenization with $10 \mathrm{~mL}$ of $1 \%$ pyrogallic acid at $30{ }^{\circ} \mathrm{C}$ for $2 \mathrm{~h}$, followed by extraction half an hour with $4 \mathrm{~mL}$ of phosphate buffer ( $\mathrm{pH} 4.5$ ) and $35 \mathrm{~mL}$ of diethyl ether under air temperature; the resultant dissolved gallic element was measured using colorimetry at $430 \mathrm{~nm}$ with absolute ether. The results were expressed as milligram gallic element per gram per $24 \mathrm{~h}$. Peroxidase activity was measured by incubating the soil or litter homogenization with $1 \mathrm{~mL}$ of $0.4 \%$ $\mathrm{H}_{2} \mathrm{O}_{2}, 2 \mathrm{~mL}$ of $0.1 \%$ ascorbic acid, and $1 \mathrm{~mL}$ of $0.02 \mathrm{M}$ pyrocatechol in a $20^{\circ} \mathrm{C}$ water bath for $2 \mathrm{~min}$, followed by extraction half an hour with $1 \mathrm{~mL}$ of $10 \%$ passivation phosphatase under air temperature; the reducing iodine was measured using a $0.005 \mathrm{M}$ iodine titration mixture to yellow (color stability $10-15 \mathrm{~s}$ ). Results were expressed as milliliters $0.005 \mathrm{M}$ iodine per gram.

The nutrient elements in litter were analyzed across decomposition time. Litter organic $\mathrm{C}$ concentration was determined using the wet digestion method with $\mathrm{K}_{2} \mathrm{Cr}_{2} \mathrm{O}_{7}$ (Yang et al. 2004), and litter $\mathrm{N}$ concentration was determined by combustion in a UK152 Distillation and Titration Unit (DK20 Heating Digester, Italy, Luan et al. 2011). Soil pH was determined using a soil/deionized water paste $(1: 2.5)$ and soil bulk density was determined using a cutting-ring method. Soil organic matter was measured by the wet digestion method with $\mathrm{K}_{2} \mathrm{Cr}_{2} \mathrm{O}_{7}$ (Soil Science Society of China 1983), soil total N, and soil available $\mathrm{P}$ were measured by the methods described by Miller and Keeney (1982).

\subsection{Statistical analysis}

The remaining dry mass of litter (\%) was calculated using

$R=\frac{M_{t}}{M_{0}} \times f \times 100 \%$

where $R$ is remaining dry mass of litter, $M_{t}$ is litter dry mass at time $t, M_{0}$ is the initial litter mass, $t$ is the sampling time interval, and $f$ is the conversion coefficient between air-dried and oven-dried litter.

The decomposition rate was estimated using a single exponential decay model (Olson 1963):

$M_{\mathrm{t}}=M_{0} e^{-k t}$

where $M_{t}$ is litter dry mass at time $t, M_{0}$ is the initial litter mass, $t$ is the sampling time interval, and $k$ is the annual decay constant.

All statistical analyses were performed using SPSS v. 18.0 (SPSS Inc., Chicago, IL, USA) and curve tracings were used by SigmaPlot v. 11.0 (Cranes Software International, Karnataka, India). Two-way ANOVAs with stand type and decomposition time as factors and three-way ANOVAs with stand type, decomposition time, and layers (litter vs. soil) indicated significant difference in means of parameters studied, and thus Fishers least significant difference (LSD) method was used to compare the differences in litter decomposition rate, nutrient dynamics, and soil-litter layer enzyme activities among the different decomposition stages within each layer (litter or soil) in each stand type. The standard 0.05 level of significance was used to designate a statistically significant 
effect. Simple linear regression was used to fit the relationships between remaining dry mass and soil-litter layer enzyme activities. Correlation analysis was used to examine the relationships among litter chemical characteristics, litter decomposition rates, and soil nutrient concentration.

\section{Results}

\subsection{Remaining dry mass of litter, nutrient, and environmental factors dynamics}

The pattern of remaining dry mass of litter was similar in the younger and the older stands, showing a fast mass loss from 270 to 360 days of decomposition especially for the younger stands (Fig. 2). The remaining litter mass was significantly larger in the older compared to the younger stands at 270 days $(P<0.05), 360$ days $(P<0.05)$, and 540 days $(P<0.05)$ (Fig. 2). At the end of the decomposition experiment, the remaining litter mass was $57.6 \%$ of the initial mass in the younger stands and $61.3 \%$ in the older stands (Fig. 2).

The litter mass loss rates were lower during the dry period from March to June (180-270 days) than during the rainy period from July to August 2011, and the decomposition rate increased with the onset of the rainy season in August. There was a generally good fit of the exponential model of decomposition using individual litterbag data (Table 2). The mean decomposition constants $(k)$ did not differ between the younger (0.29) and the older (0.30) stands.

Litter substrate quality changed with decomposition time (Fig. 3). Litter C concentration increased initially in both stands (90 days) and then declined. After 540 days of decomposition, litter $\mathrm{C}$ concentration was not significantly different $(-5.4 \% ; P=0.115)$ from the initial $\mathrm{C}$ concentration ( 0 day) in the younger stands, whereas the $\mathrm{C}$ concentration declined by $8.6 \%(P<0.05)$ from the initial $\mathrm{C}$ concentration in the older stands, showing a net $\mathrm{C}$ content release (Fig. 3a). Comparing with the initial values, litter $\mathrm{N}$ concentration at the experiment
Table 2 Regression equation and decomposition constant in P. massoniana stands

\begin{tabular}{llllll}
\hline Stands & Regression equation & $R^{2}$ & $k$ & $50 \%^{\mathrm{a}}$ & $95 \%$ \\
\hline Younger & $y=100.15 \mathrm{e}^{-0.2894 t}$ & 0.96 & 0.29 & 2.40 & 10.36 \\
Older & $y=100.88 \mathrm{e}^{-0.2983 t}$ & 0.95 & 0.30 & 2.35 & 10.07 \\
\hline
\end{tabular}

$y$ litter dry mass remaining rate, $t$ decomposition time

${ }^{\text {a }}$ Mean litter mass lose $50 \%$

${ }^{\mathrm{b}}$ Mean litter mass lose $90 \%$

end significantly increased in the younger $(+46.9 \% ; P<0.01)$ and in the older stands $(+39.1 \% ; P<0.01)$, indicating a net $\mathrm{N}$ content retention (Fig. $3 \mathrm{~b}$ ). The litter $\mathrm{C} / \mathrm{N}$ ratio decreased in both the younger $(-35.8 \%)$ and the older stands $(-34.8 \%)$ along the decomposition process, except for an increase in $\mathrm{C} / \mathrm{N}$ ratio at 180 days (Fig. 3c).

The mean soil water content and soil temperature were nearly identical between the two stands (Fig. 4). The monthly mean soil temperature ranged from $2.40{ }^{\circ} \mathrm{C}$ (in January) to $23.60{ }^{\circ} \mathrm{C}$ (in July) in the younger stands, whereas it ranged from $2.70{ }^{\circ} \mathrm{C}$ (in January) to $25.53{ }^{\circ} \mathrm{C}$ (in July) in the older stands. The annual mean soil water contents was $19.7 \%$ in the younger stands and $20.3 \%$ in the older stands, while annual mean litter layer water contents were $20.86 \%$ in the younger stands and $20.40 \%$ in the older stands. Due to continuous snow and rain, the litter layer water contents were much higher than the soil water contents in February, 2011. The older stands had higher soil nutrient concentrations than the younger stands, only soil total $\mathrm{P}$ concentration was not significantly different between the two stand types (Fig. 5).

\subsection{The dynamics of soil-litter interface enzyme activities and soil nutrient characteristics}

The activities of invertase tended to decrease with decomposition time in both litter and soil layer in P. massoniana stands (Fig. 6a, b). The activities of cellulase decreased with
Fig. 2 Litter decomposition dynamics in younger and older P. massoniana plantations (mean $\pm 1 \mathrm{SD})$
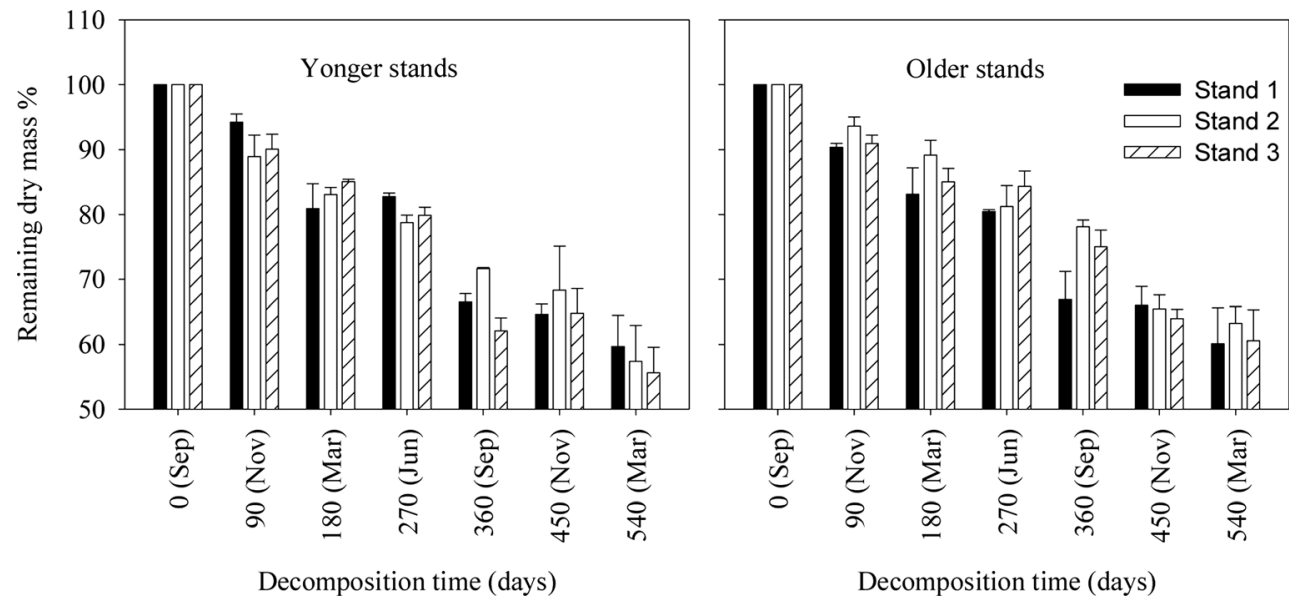


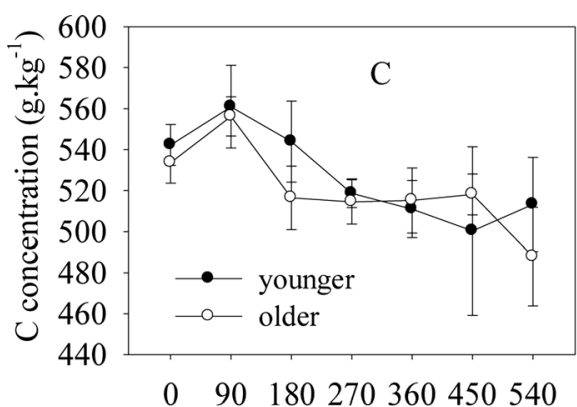

Decomposition time (days)

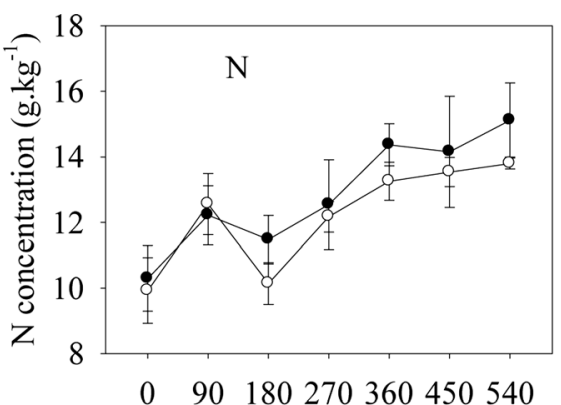

Decomposition time (days)

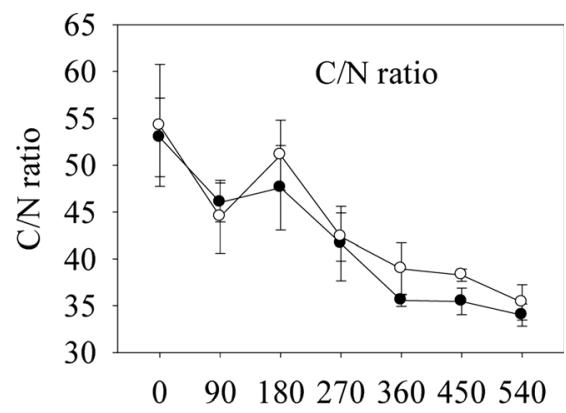

Decomposition time (days)

Fig. 3 Dynamics of litter $\mathrm{C}, \mathrm{N}$, and $\mathrm{C} / \mathrm{N}$ ratio during litter decomposition in the younger and older $P$. massoniana plantations (mean $\pm 1 \mathrm{SD}$ )

decomposition time in litter but showed a hump-shaped curve with time in soils for both stand types (Fig. 6c, d). The younger stands tended to have higher levels of urease activity than the older stands in both litter and soil (Fig. 6e, f).

Overall, the activities of invertase, cellulase, and urease showed higher levels in litter than in soil in the two stand types (Fig. 6). The invertase activity in the litter layer was 12-30 times (younger stands) and 15-21 times (older stands) greater than that in soil layer. The cellulase activity in the litter layer was 15-105 (younger stands) and 12-113 (older stands) times larger than that in soil layer. For urease activities, the concentration in the litter layer was up to 8 times greater than that in the soil layer in both stands.

Polyphenol oxidase and peroxidase activities in litter had the highest level in both stand types in March (180 days) (Fig. 7). The activities of soil layer polyphenol oxidase (Fig. 7a, b) and peroxidase (Fig. 7c, d) tended to increase with decomposition time. The litter layer tended to have higher polyphenol oxidase activities than the soil layer (Fig. 7a, b), whereas the soil layer had higher peroxidase activities than the litter layer in both stand types (Fig. 7c, d).

\subsection{Relationships of remaining dry mass and soil-litter interface enzyme activities}

Remaining dry mass was significantly negatively correlated with litter polyphenol oxidase (Fig. 8a) and urease activity (Fig. 8e) but significantly positively correlated with litter invertase (Fig. 8c) and cellulase activity (Fig. 8d). On the other hand, remaining dry mass was found to be linearly positively correlated with soil invertase activity (Fig. 9c) but negatively with activities of other soil enzymes investigated (Fig. 9).

\subsection{Factors influencing soil-litter interface enzyme activities}

Soil organic matter, soil available $\mathrm{P}$, and soil $\mathrm{pH}$ did not significantly affect the activities of both litter and soil enzymes (Table 3). Soil N concentration only significantly affected litter peroxidase activity $(P<0.01$; Table 3$)$, whereas soil moisture had a positive effect on litter urease $(P<0.05)$ and a negative effect on litter invertase $(P<0.01$; Table 3$)$. Litter $\mathrm{C}$ positively affected litter cellulase $(P<0.01)$. Litter $\mathrm{C} / \mathrm{N}$

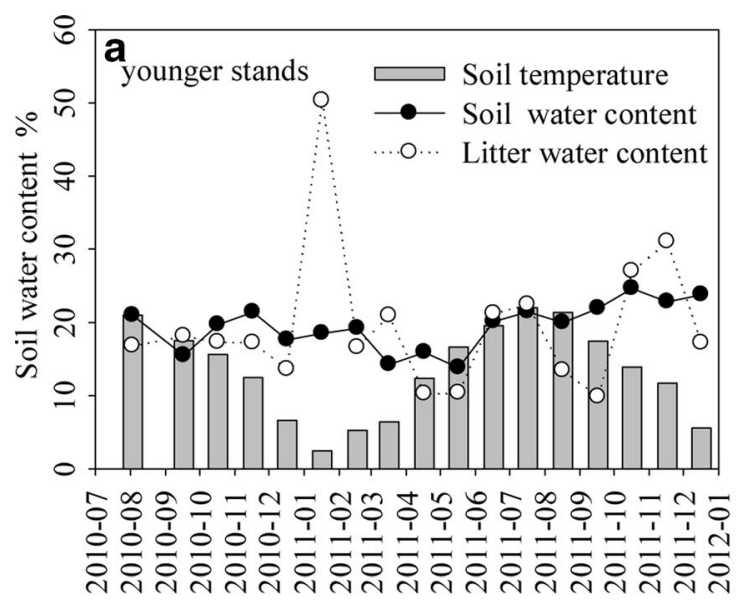

Sampling month

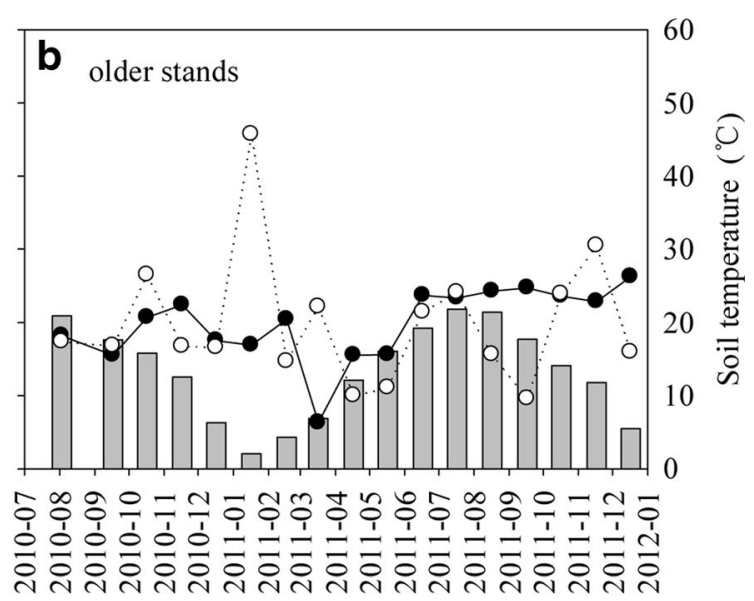

Sampling month

Fig. 4 Soil temperature, soil water content (5-cm soil depth), and litter water content in the P. massoniana stands studied during the experimental period 
Fig. 5 Soil nutrients $(0-20 \mathrm{~cm}$ soil depth)in the P. massoniana stands. Different letters in the same group indicate significant differences $(P<0.05)$ between the younger and the older stands

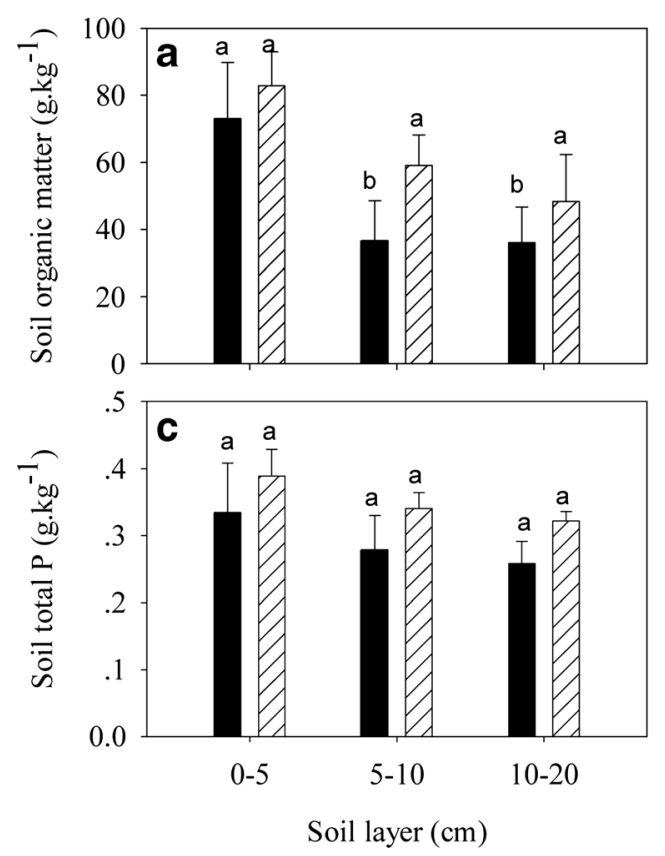

positively affected litter invertase $(P<0.05)$ but negatively affected soil polyphenol oxidase activity $(P<0.05$; Table 3$)$. Litter moisture mainly affected the litter enzyme activities, and litter $\mathrm{N}$ affected both litter and soil enzyme activities (Table 3). Soil temperature had the most significant effects on both litter and soil enzyme activities: it negatively affected litter enzymes but positively affected soil enzyme activities (Table 3).

\section{Discussion}

\subsection{Soil-litter layer enzyme activities change dynamics during decomposition}

Analysis of variation in soil enzyme activities could be helpful for estimating microbial activities during litter decomposition (Wang et al. 2011), which could be integrated into models of litter decay. This is because enzymes catalyze specific reactions and enzyme activity levels represent the immediate decomposition rate (Moorhead and Sinsabaugh 2000). Papa et al. (2014) stated that activities of invertase and cellulase were induced by inputs of soluble or easily decomposable compounds from litter. Therefore, we found that invertase and cellulase activities were high in November (90 days of decomposition time) (Fig. 6a, c), associated with higher sugar and cellulose content at the beginning of litter decomposition, and then decreased steadily as decomposition proceeded. This result may suggest that invertase and cellulase are t-strategy species.
Oxidoreductase activity associated with lignin degradation was greatest in March (180 days) and lowest in November (90 days) (Fig. 7). The high enzyme activities observed in spring could be related to favorable climate such as high water availability and moderate temperature (Papa et al. 2014) and high activity of roots (Kotroczó et al. 2014). The oxidoreductase activity was low in the initial decomposition phase and increased at later stages of decomposition when fungal biomass significantly increased (Rietl and Jackson 2012; Amin et al. 2014). Our result was consistent with the results of Zhou and Zhang (2014) but it was inconsistent with the findings of Fioretto et al. (2000) and Papa et al. (2014). This difference among studies is probably because enzyme activities might become susceptible during the soil thawing period (Wallenstein et al. 2009).

We found that the time-related variations of enzyme activity were larger in litter than in soil (Figs. 6 and 7). This may be due to litter layer enzyme activity facing greater variations in temperature, moisture, and litter chemical quality compared to changes in those factors in soils during the decomposition (Baldrian et al. 2013). Our result may also suggest that the extracellular enzymes may be stabilized in the soil matrix and can remain active over long periods (Dilly et al. 2007).

\subsection{Relationships of soil-litter interface enzyme activities and remaining dry mass}

In line with our hypothesis I, we found that there were significant linear relationships between soil-litter interface enzyme activities and remaining dry mass (Figs. 8 and 9), except for litter layer peroxidase activities (Fig. 8b). This result 

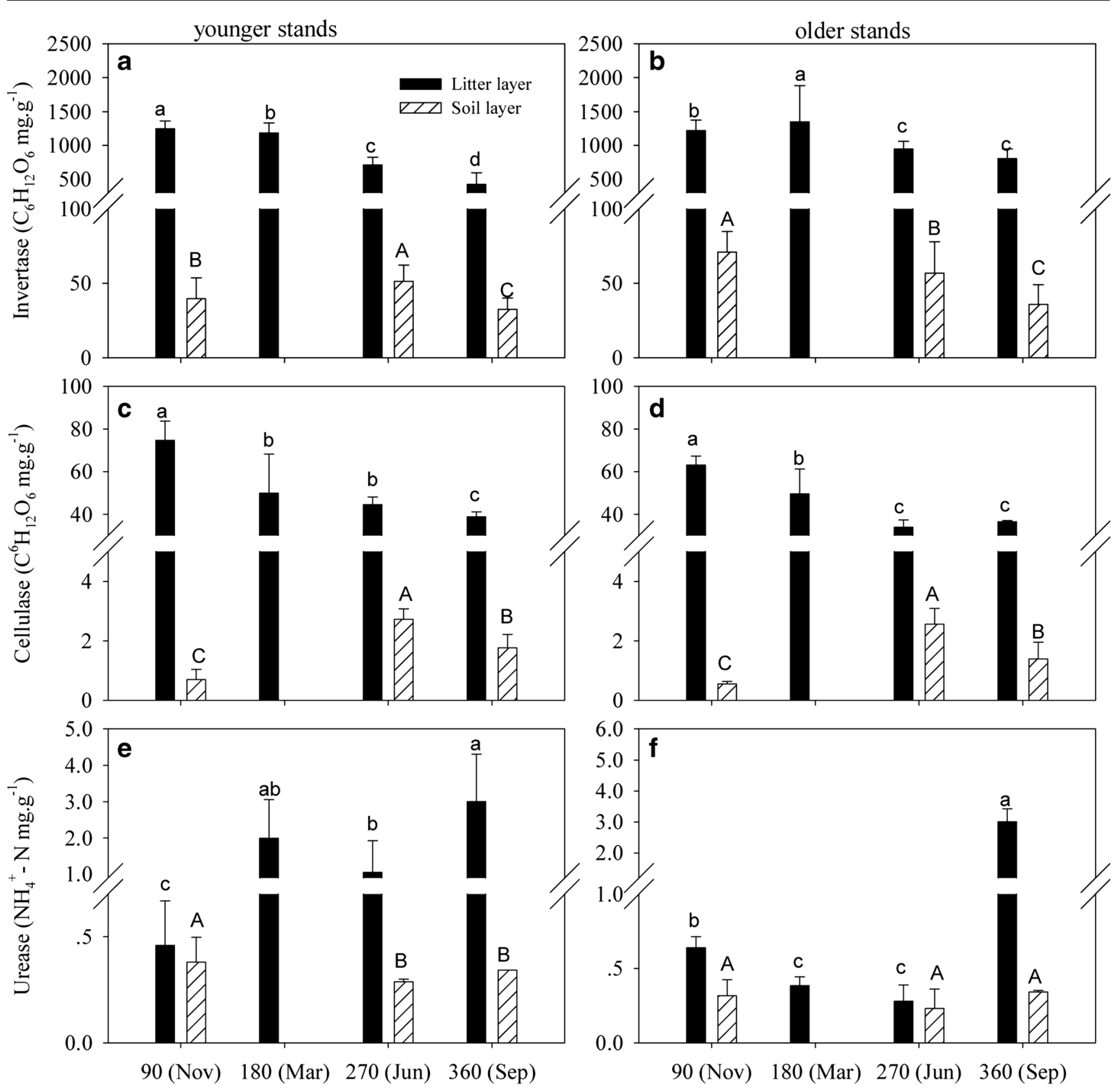

Decomposition time (days)

Fig. 6 Hydrolase activities in litter and soil layer in P. massoniana stands (mean $\pm 1 \mathrm{SD}$ ). Different lowercase letters indicate significant differences $(P<0.05)$ in enzyme activities in litter during decomposition time, and

confirmed that the activities of litter-soil layer microbial extracellular enzymes play an important role in the decomposition of leaf litter (Smart and Jackson 2009). Allison and Vitousek (2004) showed that $52 \%$ of the variation in decomposition was explained by cellobiohydrolase and polyphenol oxidase activities. Temporal patterns in litter decomposition correspond, therefore, to activity levels of degradative enzymes. Litter decomposition releases a large quantity of soluble and insoluble carbohydrates, which can stimulate

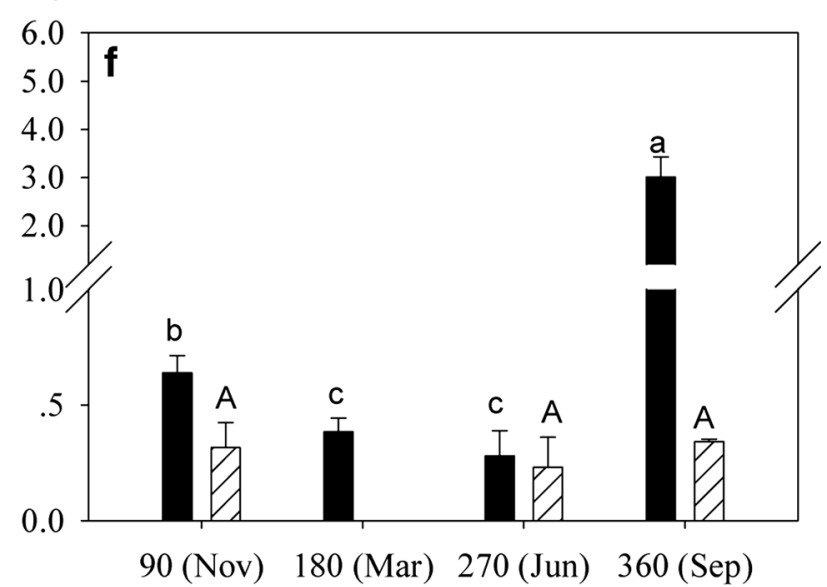

Decomposition time (days)

different capital letters indicate significant differences $(P<0.05)$ for enzyme activities in the soil layer during the experimental period

microbial diversity, biomass, and thus also activity. Of course, the activity of these enzymes during decomposition process may also be related to climatic factors and soil chemical properties (Keiblinger et al. 2012).

Remaining dry mass was negatively correlated with soil layer cellulase enzyme (Fig. 9d) but it was positively correlated with litter layer cellulase activity (Fig. 8d). This result may be caused by the divergence of cellulase activity in litter and soil during the decomposition process, i.e., decreased activity 

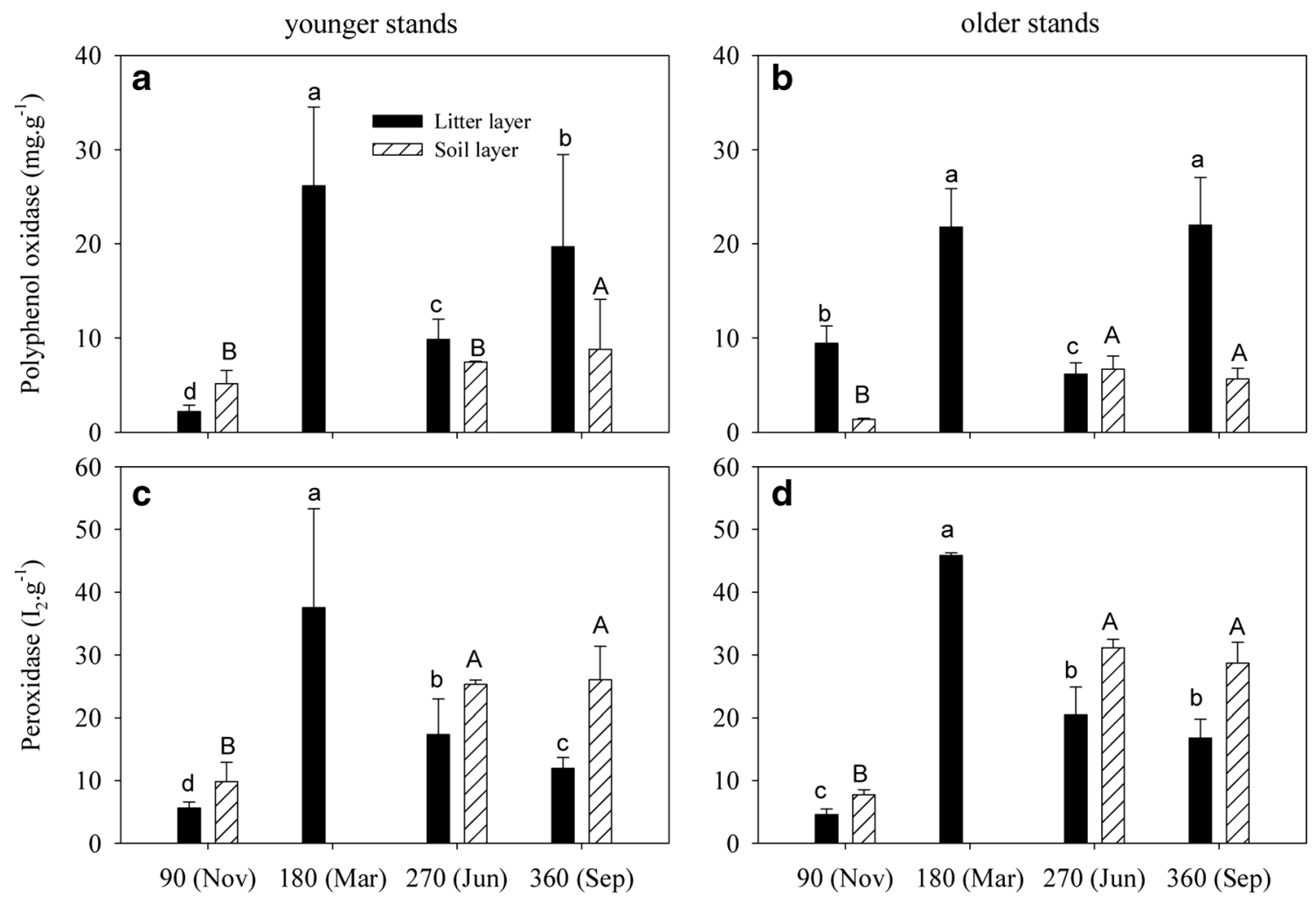

Decomposition time (days)

Fig. 7 Oxidoreductase activities in upper soil-litter layers on $P$. massoniana plantations (mean $\pm 1 \mathrm{SD}$ ). Different lowercase letters indicate significant differences $(P<0.05)$ for enzyme activities in the

litter during the decomposition period, and different capital letters indicate significant difference $(P<0.05)$ in enzyme activities in soil layer across the experimental period
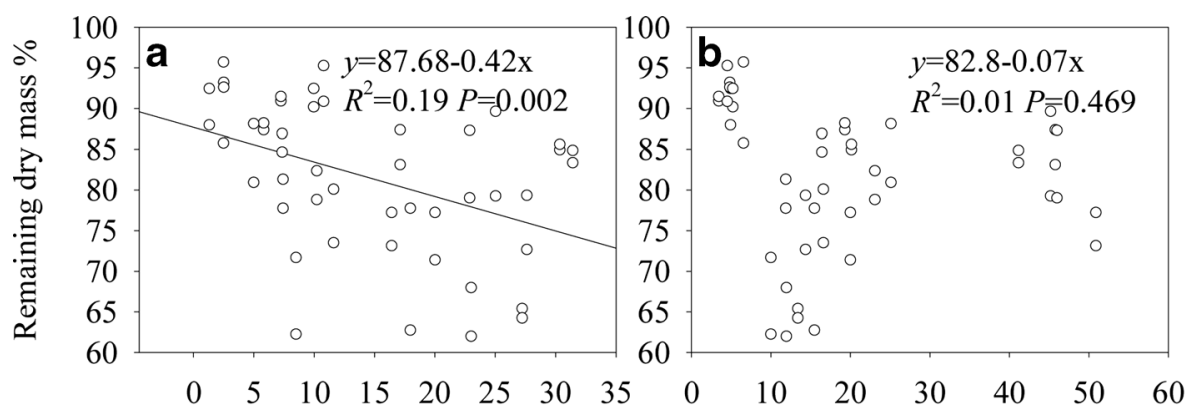

Litter polyphenol oxidase $\left(\mathrm{mg} \cdot \mathrm{g}^{-1}\right)$

Litter peroxidase $\left(\mathrm{I}_{2} \mathrm{mg} \cdot \mathrm{g}^{-1}\right)$
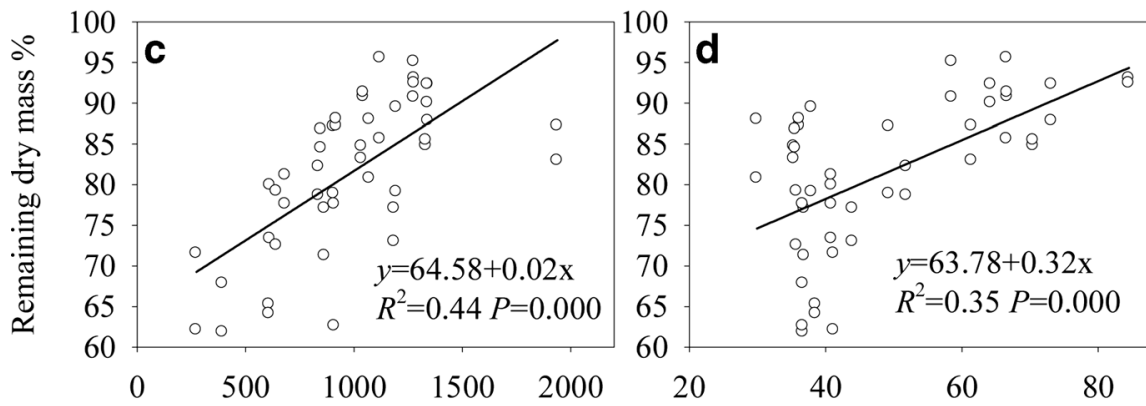

Litter invertase $\left(\mathrm{C}_{6} \mathrm{H}_{12} \mathrm{O}_{6} \mathrm{mg} \cdot \mathrm{g}^{-1}\right)$

Litter cellulase $\left(\mathrm{C}_{6} \mathrm{H}_{12} \mathrm{O}_{6} \mathrm{mg} \cdot \mathrm{g}^{-1}\right)$

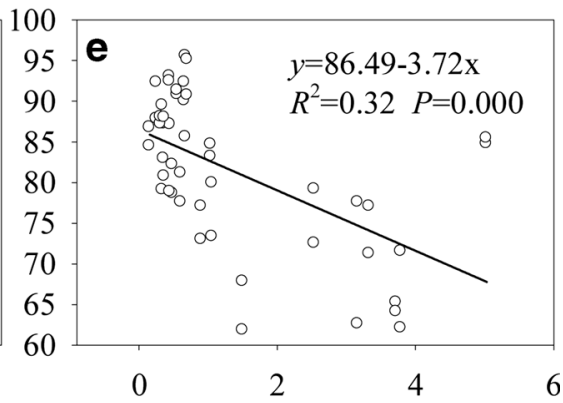

Litter urease $\left(\mathrm{NH}_{4}^{+}-\mathrm{N} \mathrm{mg} \cdot \mathrm{g}^{-1}\right)$

Fig. 8 Remaining dry mass in relation to litter layer enzyme activities in P. massoniana plantations 

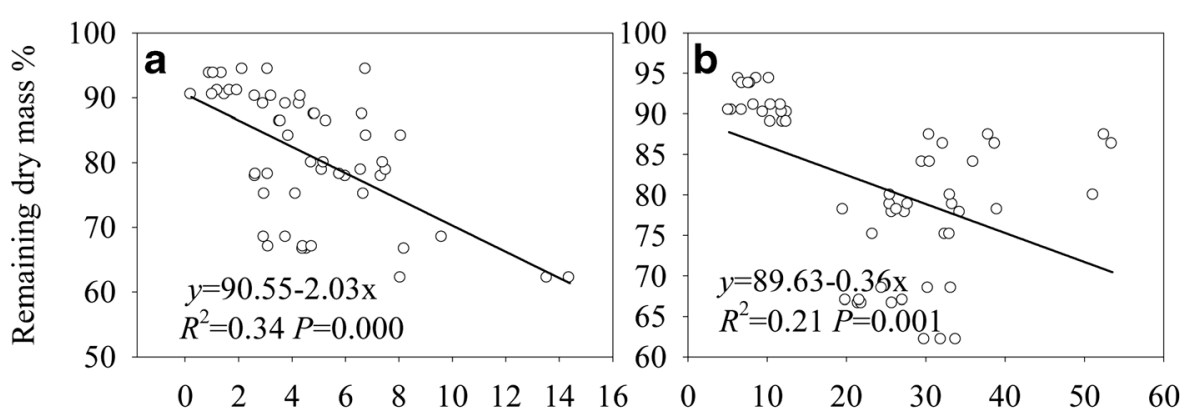

Soil polyphenoloxidase $\left(\mathrm{mg} \cdot \mathrm{g}^{-1}\right)$

Soil peroxidase $\left(\mathrm{I}_{2} \mathrm{mg} \cdot \mathrm{g}^{-1}\right)$
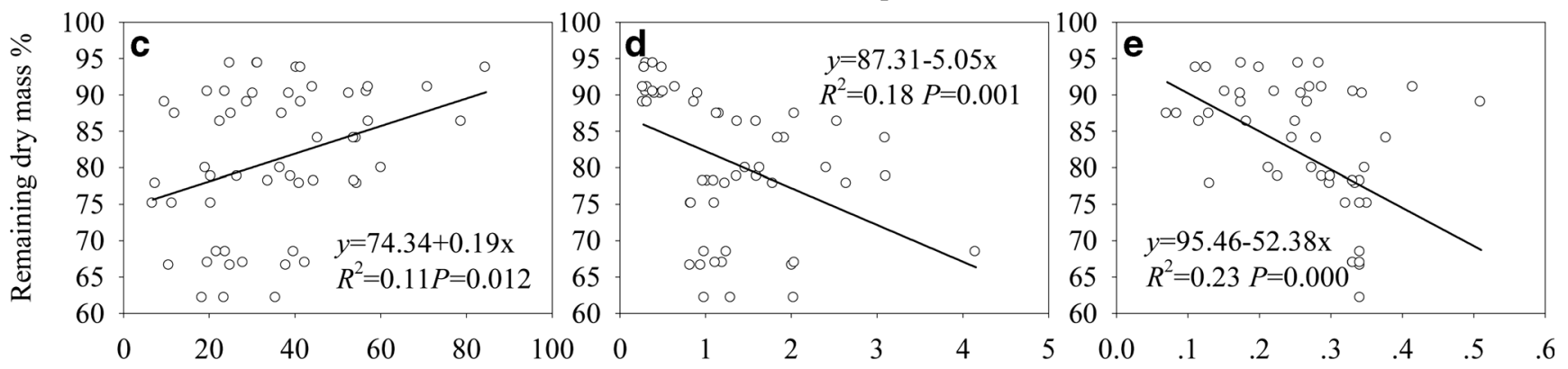

Soil invertase $\left(\mathrm{C}_{6} \mathrm{H}_{12} \mathrm{O}_{6} \mathrm{mg} \cdot \mathrm{g}^{-1}\right)$

Soil cellulase $\left(\mathrm{C}_{6} \mathrm{H}_{12} \mathrm{O}_{6} \mathrm{mg} \cdot \mathrm{g}^{-1}\right)$

Soil urease $\left(\mathrm{NH}_{4}^{+}-\mathrm{N} \mathrm{mg} \cdot \mathrm{g}^{-1}\right)$

Fig. 9 Remaining dry mass in relation to soil layer enzyme activities in P. massoniana plantations

of cellulase in litter but increased activity of cellulase in soil during decomposition (Fig. 6c, d). Two main reasons were employed to explain the results. First, the litter layer cellulase activity slowly increased and stayed at higher levels for a long time during litter decomposition (Joshi et al. 1993). Similar to our results (Fig. 8d), Fioretto et al. (2000) showed that cellulase activities seemed to delay decomposition at later decomposition stages in Mediterranean ecosystems. Second, fungi decomposes energy-rich substrates in soil to supply energy for the energetically decay of lignin in the litter. These also suggest that rapid decomposition exhausts the simple sugars, thereafter lignin breakdown dominates (Allison and Vitousek 2004).

We found that remaining dry mass was significantly negatively correlated with the urease activity in both litter (Fig. 8e) and soil layers (Fig. 9e). The activity of urease (N-acquiring

Table 3 Soil-litter layer enzyme activities in relation to soil parameters and litter quality

\begin{tabular}{|c|c|c|c|c|c|c|c|c|c|c|}
\hline \multirow[t]{2}{*}{ Enzyme activities } & \multicolumn{6}{|l|}{ Soil } & \multicolumn{4}{|l|}{ Litter } \\
\hline & Soil organic matter & Soil N & $\mathrm{AP}$ & $\mathrm{pH}$ & Soil T & Soil M & Litter M & Litter C & Litter N & Litter $\mathrm{C} / \mathrm{N}$ \\
\hline \multicolumn{11}{|c|}{ Litter layer enzyme activities } \\
\hline Polyphenoloxidase & - & - & - & - & - & - & - & - & - & - \\
\hline Peroxidase & - & $-0.555^{* *}$ & - & - & $-0.562 * *$ & - & $0.464 *$ & - & $-0.560 * *$ & - \\
\hline Urease & - & - & - & - & - & $0.425 *$ & $-0.623 * *$ & - & - & - \\
\hline Cellulase & - & - & - & - & $-0.438^{*}$ & - & - & $0.737 * *$ & - & - \\
\hline Invertase & - & - & - & - & $-0.663 * *$ & $-0.619 * *$ & $0.425 *$ & - & $-0.593 * *$ & $0.430 *$ \\
\hline \multicolumn{11}{|c|}{ Soil layer enzyme activities } \\
\hline Polyphenoloxidase & - & - & - & - & $0.691 * *$ & - & - & - & $0.504 *$ & $-0.473 *$ \\
\hline Peroxidase & - & - & - & - & $0.903 * *$ & - & - & - & $0.550^{*}$ & - \\
\hline Urease & - & - & - & - & - & - & - & - & - & - \\
\hline Cellulase & - & - & - & - & $0.810^{* *}$ & - & - & - & - & - \\
\hline Invertase & - & - & - & - & - & - & $0.612 * *$ & - & $-0.476^{*}$ & - \\
\hline
\end{tabular}

Soil $N$ soil nitrogen, $A P$ soil available phosphorus, Soil $M$ soil moisture, Litter $M$ litter moisture, Soil $T$ soil temperature

$* P<0.05 ; * * P<0.01$ 
enzyme) is involved in hydrolysis of urea-type substrates (Song et al. 2014), and hence, our result may be correlated with increasing nitrogen concentration in litter (Fig. 3).

Allison and Vitousek (2004) found that polyphenol oxidase activities were significantly positively correlated with litter decomposition rates, and polyphenol oxidase activity increased with progressive decay (Moorhead and Sinsabaugh 2000), as some acid-insoluble compounds were transferred from litter into soil $\mathrm{C}$ pools. The relationships between enzyme activities and remaining dry mass might be direct and also indirect because many biotic and abiotic factors can influence enzyme activity after enzymes are generated (Sinsabaugh and Moorhead 1994; Allison and Vitousek 2004). In general, hydrolase activity plays a role in decomposition at early stages, and oxidoreductase dominates the decomposition of organic residues (e.g., lignin; i.e., at later stages). However, further studies are needed to better understand the mechanistic link between soil-litter layer extracellular enzyme and litter decomposition rate.

\subsection{Factors influencing soil-litter interface enzyme activities}

In the litter layer, litter chemistry and substrate quality regulate enzyme activities, which further influence the diversity and structure of decomposer communities (Papa et al. 2014). In this study, we found that the enzyme activity level was higher in litter layer than in soil layer (Figs. 6 and 7), which clearly indicated a positive effect of the substrate quality and quantity on enzyme activities (Andersson et al. 2004). Both the quantity and quality of decomposing materials differ between litter and soil, and litter usually change more rapidly over time, and the ratios of $\mathrm{C} / \mathrm{N}$ and $\mathrm{C} / \mathrm{P}$ are higher in litter than in soil (Moorhead et al. 2016), which leads to greater enzyme activity in litter than in mineral soil (Ma et al. 2014).

Many studies reported that litter quality such as higher nutrient availability and a high $\mathrm{C} / \mathrm{N}$ ratio of litter (Fioretto et al. 2000), could influence enzyme activities in soil and litter during decomposition (Conn and Dighton 2000; Hu et al. 2006). In this study, we found that litter layer invertase activity was significantly positive but soil layer polyphenol oxidase activity significantly negatively correlated with litter $\mathrm{C} / \mathrm{N}$ ratio (Table 3), indicating that litter chemistry regulates microbial enzyme production and influences the diversity or structure of decomposer communities (Waring 2013), and thus determines the soil-litter enzyme activity. This may be because the chemical and physical properties of litter can change the relationship between enzyme activities and decomposition by altering the effectiveness and stability of microbial enzymes (Allison and Vitousek 2004). On the other hand, the effects of litter quality on enzyme activities may also be modified by microclimatic conditions such as moisture that showed difference between litter and soil layer (Fig. 4).
We found that litter $\mathrm{N}$ was one of the most important factors affecting enzyme activities (Table 3). A previous study showed that enzymatic responses such as the induction of $\mathrm{N}$-mineralizing enzymes were correlated with rapidly decomposing matter (Dilly et al. 2007). Our results found that litter $\mathrm{N}$ concentration was negatively correlated with peroxidase and invertase in litter, but positively correlated with polyphenol oxidase and peroxidase in soil (Table 3). This suggested that litter and soil enzymes differed in their responses to litter $\mathrm{N}$ content during litter decomposition. Chigineva et al. (2011) found that litter $\mathrm{N}$ concentration could partly compensate for the negative effect of sucrose on the synthesis of phenoloxidase. Güsewell and Freeman (2005) and Waring et al. (2013) showed that the relationships between enzyme activities and litter $\mathrm{N}$ concentrations depended on litter type. Their results suggest that species identity associated with litter nutrient availability has a greater influence on enzyme activity and further on litter decomposition rate in different decomposition stage. Moorhead and Sinsabaugh (2000) reported that microbial $\mathrm{N}$ limitation can occur due to high microbial $\mathrm{N}$ demand during the early stages of decomposition.

In line with our hypothesis II, we found that soil temperature and litter moisture were the two most important abiotic factors influencing the enzyme activities (Table 3). Soil temperature and litter moisture with relatively large seasonal variation (Fig. 4) can alter microbial community structure and function. Keiblinger et al. (2012) and Žifčáková et al. (2016) found that litter moisture was related to the fungal responses in terms of metabolic activity (Keiblinger et al. 2012). Fungi responded directly to rainfall levels. More rainfall led to more abundant, diverse, and consistent fungi communities (Hawkes et al. 2011), which may explain why litter moisture rather than soil moisture significantly influenced the enzyme activities (Table 3). Thus, climatic factors have previously been identified as major causes of the observed seasonal differences in litter decomposition due to alterations the extracellular enzymes (Wallenstein et al. 2009; Henry 2012; Baldrian et al. 2013; Bear et al. 2014).

Except for litter N, we did not find significant effects of soil organic matter, soil $\mathrm{N}$ (only for litter peroxidase) and $\mathrm{P}$ concentration, and soil $\mathrm{pH}$ value on soil-litter interface enzyme activities (Table 3), indicating that litter plays a more important role than soil in controlling enzyme activities, and that the relative activities of $\mathrm{C}$ and $\mathrm{P}$ acquiring enzymes are unconstrained by nutrients use efficiency (Moorhead et al. 2016), which supported the results of Sinsabaugh (2010) and Allison and Vitousek (2004). Therefore, the difference in enzyme activities between litter and soil layers or the activity of littersoil interface enzymes are mainly determined by the litter rather than soil (Table 3 ). 


\section{Conclusions}

The faster litter decomposition in the younger stands than in the older stands (Fig. 2) may be a direct result of higher $\mathrm{N}$ concentration and lower $\mathrm{C} / \mathrm{N}$ ratio of litter in the former than in the latter one (Fig. 3). Soil temperature, litter moisture, and litter $\mathrm{N}$ concentration were the most important factors determining the soil-litter interface enzyme activities (Table 3), and there were consistent linear relationships between remaining dry mass and soil-litter interface enzyme activities (Figs. 8 and 9). The activity of the soil-litter interface enzymes was determined by the litter associated with its chemical quality and climatic conditions (e.g., moisture) rather than by soil. Our findings will help to elucidate the complex litter decomposition process and emphasize the need for a better understanding of the mechanistic link between soil-litter extracellular enzyme production and litter decomposition.

Acknowledgments This study was supported by National Natural Science Foundation of China (31400531), the National Key Research and Development Program of China (2016YF0600202), the Fundamental Research Funds for the Central Non-profit Research Institution (CAFRIFEEP201101 and CAFBB2014QA008), the Chinese forestry industry, research and special public welfare (Project No. 201104008), Zigui Forest Ecosystem Research Station of State Forestry Administration and CFERN\&GENE Award Funds on Ecological Paper. We are grateful to the staff of the Key Laboratory of Forest Ecology and Environment for chemical analysis. We also thank anonymous reviewers for helpful suggestions on the manuscript. Xiaogai Ge and Wenfa Xiao contributed equally to this work.

\section{References}

Allison SD, Vitousek PM (2004) Extracellular enzyme activities and carbon chemistry as drivers of tropical plant litter decomposition. Biotropica 36:285-296

Amin BAZ, Chabbert B, Moorhead D, Bertrand I (2014) Impact of fine litter chemistry on lignocelluolytic enzyme efficiency during decomposition maize leaf and root in soil. Biogeochemistry 117: 169-183

Andersson M, Kj $\varphi$ ller A, Struwe S (2004) Microbial enzyme activities in leaf litter, humus and mineral soil layers of European forests. Soil Biol Biochem 36:1527-1537

Baldrian P, Šnajdr J, Merhautová V, Dobiášová P, Cajthaml T, Valášková V (2013) Responses of the extracellular enzyme activities in hardwood forest to soil temperature and seasonality and the potential effects of climate change. Soil Biol Biochem 56:60-68

Bear ADA, Jones TH, Kandeler E, Lynne Boddy L (2014) Interactive effects of temperature and soil moisture on fungal-mediated wood decomposition and extracellular enzyme activity. Soil Biol Biochem 70:151-158

Chigineva NI, Aleksandrova AV, Marhan S, Kandeler E, Tiunov AV (2011) The importance of mycelial connection at the soil-litter interface for nutrient translocation, enzyme activity and litter decomposition. Appl Soil Ecol 51:35-41

Conn C, Dighton J (2000) Litter quality influences on decomposition, ectomycorrhizal community structure and mycorrhizal root surface acid phosphatase activity. Soil Biol Biochem 32:489-496
Dilly O, Munch JC, Pfeiffer EM (2007) Enzyme activities and litter decomposition in agricultural soils in northern, central, and southern Germany. J Plant Nutr Soil Sci 170:197-204

Fioretto A, Papa S, Curcio E, Sorrentino G, Fuggi A (2000) Enzyme dynamics on decomposing leaf litter of Cistus incanus and Myrtus communis in a Mediterranean ecosystem. Soil Biol Biochem 32: $1847-1855$

German DP, Weintraub MN, Grandy AS, Lauber CL, Rinkes ZL, Allison SD (2011) Optimization of hydrolytic and oxidative enzyme methods for ecosystem studies. Soil Biol Biochem 43:1387-1397

Gong ZT (2003) Chinese soil taxonomy (revised proposal). China Science Press, Beijing

Güsewell S, Freeman C (2005) Nutrient limitation and enzyme activities during litter decomposition of nine wetland species in relation to litter N:P ratios. Funct Ecol 19:582-593

Guan SY (1986) Soil enzyme and its research methods. China Agriculture Press, Beijing

Hawkes CV, Kivlin SN, Rocca JD, Huguet V, Thomsen MA, Suttle KB (2011) Fungal community responses to precipitation. Glob Chang Biol 17:1637-1645

Henry HAL (2012) Soil extracellular enzyme dynamic in a changing climate. Soil Biol Biochem 47:53-59

Hu YL, Wang SL, Zeng DH (2006) Effects of single Chinese fir and mixed leaf litters on soil chemical, microbial properties and soil enzyme activities. Plant Soil 282:379-386

Joshi SR, Sharma GD, Mishra RR (1993) Microbial enzyme activities related to litter decomposition near a highway in a sub-tropical forest of northeast India. Soil Biol Biochem 12:1763-1770

Keiblinger KM, Schneider T, Roschitzki B, Schmid E, Eberl L, Hämmerle I, Leitner S, Richter A, Wanek W, Riedel K, Zechmeister-Boltenstern S (2012) Effects of stoichiometry and temperature perturbations on beech leaf litter decomposition, enzyme activities and protein expression. Biogeosciences 9:4537-4551

Kourtev PS, Ehrenfeld JG, Huang WZ (2002) Enzyme activities during litter decomposition of two exotic and two native plant species in hardwood forests of New Jersey. Soil Biol Biochem 34:1207-1218

Kotroczó Z, Veres Z, Fekete I, Krakomperger Z, Tóth JA, Lajtha K, Tóthmérész B (2014) Soil enzyme activity in response to longterm organic matter manipulation. Soil Biol Biochem 70:237-224

Kshattriya S, Sharma GD, Mishra RR (1992) Enzyme activities related to litter decomposition in forests of different age and altitude in north east India. Soil Biol Biochem 24:265-270

Luan JW, Liu SR, Zhu XL, Wang JX (2011) Soil carbon stocks and fluxes in a warm-temperate oak chronosequence in China. Plant Soil 34: $243-253$

Ma YC, Zhu B, Sun ZZ, Zhao C, Yang Y, Piao SL (2014) The effects of simulated nitrogen deposition on extracellular enzyme activities of litter and soil among different-aged stands of larch. J Plant Ecol 3: 240-249

Melillo JM, Aber JD, Muratore JF (1982) Nitrogen and lignin control of hardwood leaf litter decomposition dynamics. Ecology 63:621-626

Miller RH, Keeney DR (1982) Methods of soil analysis, 2nd edn. American Society of Agronomy, Soil Science Society of America, Madison

Moorhead DL, Sinsabaugh RL, Hill BH, Weintraub MN (2016) Vector analysis of ecoenzyme activities reveal constraints on coupled C, N and P dynamics. Soil Biol Biochem 93:1-7

Moorhead DL, Sinsabaugh RL (2000) Simulated patterns of litter decay predict pattern of extracellular enzyme activities. Appl Soil Ecol 14: 71-79

Olson JS (1963) Energy storage and the balance of producers and decomposers in ecological systems. Ecology 44:322-331

Papa S, Cembrola E, Pellegrino A, Fuggi A, Fioretto A (2014) Microbial enzyme activities, fungal biomass and quality of the litter and upper soil layer in a beech forest of south Italy. Eur J Soil Sci 65:274-285 
Prescott CE (2005) Do rates of litter decomposition tell us anything we really need to know? Forest Ecol Manag 220:66-74

Qasemian L, Guiral D, Ziarelli F, Dang TKV, Farnet AM (2012) Effects of anthracene on microbial activities and organic matter decomposition in a Pinus halepensis litter from a Mediterranean coastal area. Soil Biol Biochem 46:148-154

Rietl AJ, Jackson CR (2012) Effects of the ecological restoration practices of prescribed burning and mechanical thinning on soil microbial enzyme activities and leaf litter decomposition. Soil Biol Biochem 50:47-57

Sariyildiz T (2008) Effects of gap-size classes on long-term litter decomposition rates of beech, oak and chestnut species at high elevations in Northeast Turkey. Ecosystems 11:841-853

Smart KA, Jackson CR (2009) Fine scale patterns in microbial extracellular enzyme activity during leaf litter decomposition in a stream and its floodplain. Microbial Ecol 58:591-598

Sinsabaugh RL, Moorhead DL (1994) Resource allocation to extracellular enzyme production: a model for nitrogen and phosphorus control of litter. Soil Biol Biochem 26:1305-1311

Sinsabaugh RL (2010) Phenol oxidase, peroxidase and organic matter dynamics of soil. Soil Biol Biochem 42:391-404

Sinsabaugh RL, Antibus RK, Linkins AE (1991) An enzymic approach to the analysis of microbial activity during plant litter decomposition. Agric Ecosyst Environ 34:43-54

Soil Science Society of China ACC (1983) General analysis methods of soil agriculture chemistry. Science Press, Beijing

Song XZ, Zhang HL, Chang SX, Jiang H, Peng CH, Yu SQ (2012) Elevated UV-B radiation increased the decomposition of Cinnamomum camphora and Cyclobalanopsis glauca leaf litter in subtropical China. J Soils Sediments 12:307-311

Song YY, Song CC, Tao BX, Wang JY, Zhu XY, Wang XW (2014) Shortterm responses of soil enzyme activities and carbon mineralization to added nitrogen and litter in freshwater marsh of Northeast China. Eur J Soil Biol 61:72-79

Sundarapandian SM, Swamy PS (1999) Litter production and leaf-litter decomposition of selected tree species in tropical forests at Kodayar in the western Ghats, India. Forest Ecol Manag 123:231-244
Talbot JM, Martin F, Kohler A, Henrissat B, Peay KG (2015) Functional guild classification predicts the enzymatic role of fungi in litter and soil biogeochemistry. Soil Biol Biochem 88:441-456

Wallenstein MD, McMahon SK, Schimel JP (2009) Seasonal variation in enzyme activities and temperature sensitivities in Arctic tundra soils. Glob Chang Biol 15:1631-1639

Wang H, Liu SR, Wang JX, Shi ZM, Lu LH, Guo WF, Jia HY, Cai DX (2013) Dynamics and speciation of organic carbon during decomposition of leaf litter and fine roots in four subtropical of China. Forest Ecol Manag 300:43-52

Wang CY, Han GM, Jia Y, Feng XG, Tian XJ (2011) Insight into the temperature sensitivity of forest litter decomposition and soil enzymes in subtropical forest in China. J Plant Ecol 4:1-8

Wang QK, Wang SL, Liu YX (2008) Responses to N and P fertilization in a young Eucalyptus dunnii plantation: microbial properties, enzyme activities and dissolved organic matter. Appl Soil Ecol 40:484-490

Waring BG (2013) Exploring relationships between enzyme activities and leaf litter decomposition in a wet tropical forest. Soil Biol Biochem 64:89-95

Xiao WF, Ge XG, Zeng LX, Huang ZL, Lei JP, Zhou BZ, Li MH (2014) Rates of litter decomposition and soil respiration in relation to soil temperature and water in different aged Pinus massoniana forests in the three gorges reservoir area, China. PLoS One 7:e101890

Xuluc-Tolosa FJ, Vester HFM, Ramírez-Marcial N, Castellanos-Albores J, Lawrence D (2003) Leaf litter decomposition of tree species in three successional phases of tropical dry secondary forest in Campeche, Mexico. Forest Ecol Manag 174:401-412

Yang YS, Guo JF, Chen GS, Xie JS, Cai LP, Lin P (2004) Litterfall, nutrient return, and leaf-litter decomposition in four plantations compared with a natural forest in subtropical China. Ann Forest Sci 61:465-476

Žifčáková L, Větrovský T, Howe A, Baldrian P (2016) Microbial activity in forest soil reflects the changes in ecosystem properties between summer and winter. Environ Microbiol 18:288-301

Zhou XB, Zhang YM (2014) Temporal dynamics of soil oxidative enzyme activity across a simulated gradient of nitrogen deposition in the Gurbantunggut Desert, northwestern China. Geoderma 213: 261-267 